\title{
Effects of various divalent cations on the survival of Neisseria gonorrhoeae in liquid media
}

\author{
TOLU ODUGBEMI, MICHAEL MCENTEGART, AND SALEEM HAFIZ \\ From the Department of Medical Microbiology, University of Sheffield Medical School, Sheffield
}

SUMMARY The effect of various concentrations of divalent cations on survival of gonococci in liquid medium was studied. The growth of Neisseria gonorrhoeae was inhibited by manganous chloride in concentrations above $1 \times 10^{-5} \mathrm{~mol} / \mathrm{l}$ while the growth of control organisms such as Neisseria meningitidis and Escherichia coli was not inhibited by the same salt even at $1 \times 10^{-2} \mathrm{~mol} / 1$. Copper sulphate, cobaltous nitrate, nickel chloride, and zinc sulphate also had deleterious effects on gonococci. Magnesium chloride at $1.5 \times 10^{-1} \mathrm{~mol} / \mathrm{l}$ permitted the growth of gonococci. The toxicity of manganous chloride and copper sulphate in the liquid media was in some measure reduced by adding charcoal but not by adding starch. The significance of these findings is discussed in relation to the efficiency of primary isolation and transport media for gonococci.

\section{Introduction}

Müeller and Hinton (1941) first reported satisfactory primary growth of gonococci on a solid medium free of animal protein but incorporating starch which, they suggested, acted as a 'protective colloid' against the inhibiting effects of certain amino-acids. Glass and Kennett (1939) had already shown that particulate carbon had a protective effect on gonococci in liquid media. In a study aimed at identifying inhibitory substances present in commercial agars Ley and Müeller (1946) identified a substance which was similar to a fatty acid.

Recently, Miller et al. (1977) studied the inhibitory action on the growth of Neisseria gonorrhoeae of the fatty acids commonly present in media and showed that such inhibition of growth increased with increasing chain length of the saturated fatty acids up to a maximum with palmitic acid (C16). Unsaturated fatty acids with chain lengths of $\mathrm{C} 16$ to C20 were also found to be inhibitory.

If the development of media for the study of gonococci is to be other than empirical, it is essential to increase our understanding of the effect various components have on the growth of gonococci. Bridson and Brecker (1970) found various concentrations of the divalent cations manganese $\left(\mathrm{Mn}^{++}\right)$, copper $\left(\mathrm{Cu}^{++}\right)$, nickel $\left(\mathrm{Ni}^{++}\right)$, and cobalt $\left(\mathrm{Co}^{++}\right)$in

Address for reprints: T. Odugbemi, Department of Medical Microbiology, University of Sheffield Medical School, Beech Hill Road, Sheffield S10 2RX

Received for publication 24 February 1978 peptones and agar; it therefore seemed a useful starting point to study the effect of these substances on gonococci. We therefore incorporated concentrations of manganous chloride, copper sulphate, cobaltous nitrate, nickel chloride, zinc sulphate, and magnesium sulphate into ANM media (Hafiz and McEntegart, 1976) and studied their effect on the survival of gonococci.

\section{Materials and methods}

\section{MEDIA}

The studies were carried out in liquid medium, ANM, which was prepared as follows: proteose peptone (Difco 3) $15 \mathrm{~g}$, sodium chloride (Analar) $5 \mathrm{~g}$, dipotassium phosphate (Analar) $4 \mathrm{~g}$, potassium di-hydrogen phosphate (Analar) $1 \mathrm{~g}$, soluble starch (Analar) $1 \mathrm{~g}$, sodium bicarbonate (Analar) $0 \cdot 15 \mathrm{~g}$, glucose (Analar) $5 \mathrm{~g}$, and distilled water 1 litre.

This basic liquid medium was adjusted to $\mathrm{pH}$ $7 \cdot 2$ with $\mathrm{N} / \mathrm{NaOH}$ (the endpoint being read by means of an EIL laboratory pH meter no. 7020) and sterilised by autoclaving at $110^{\circ} \mathrm{C}$ for $10 \mathrm{~min}$. Solutions were sterilised by filtering through a standard Seitz filter using EK/5 (sterilising grade) pads. Filtration was preferred to autoclaving which might have caused precipitation. Solutions of the following salts were processed and added to the liquid media to give the following final concentrations: 
Manganous chloride $\left(\mathrm{MnCl}_{2} \cdot 4 \mathrm{H}_{2} \mathrm{O}\right) 1 \times 10^{-2} \mathrm{~mol} / \mathrm{l}$ to $2 \times 10^{-6} \mathrm{~mol} / 1$

Cupric sulphate $\left(\mathrm{CuSO}_{4} \cdot 5 \mathrm{H}_{2} \mathrm{O}\right) 4 \times 10^{-4} \mathrm{~mol} / \mathrm{l}$ to $4 \times 10^{-6} \mathrm{~mol} / 1$

Cobaltous nitrate $\mathrm{Co}\left(\mathrm{NO}_{3}\right) 2.6 \mathrm{H}_{2} \mathrm{O} 2 \times 10^{-3}$ $\mathrm{mol} / \mathrm{l}$ to $5 \times 10^{-5} \mathrm{~mol} / \mathrm{l}$

Nickel chloride $\left(\mathrm{NiCl}_{2} 6 \mathrm{H}_{2} \mathrm{O}\right) 2 \times 10^{-3} \mathrm{~mol} / \mathrm{l}$ to $2 \times 10^{-4} \mathrm{~mol} / 1$

Magnesium chloride $\left(\mathrm{MgCl}_{2} \cdot 7 \mathrm{H}_{2} \mathrm{O}\right) 1.5 \times 10^{-1}$ $\mathrm{mol} / \mathrm{l}$ to $1 \times 10^{-3} \mathrm{~mol} / 1$.

All the salts were analytical reagent grade from BDH Laboratories. The media containing the various cations were distributed in $10 \mathrm{ml}$ volumes in universal containers.

\section{STRAINS}

The following strains of $N$. gonorrhoeae were used in the study: F62 (originally isolated in Kellogg's laboratory and stored in liquid nitrogen in our laboratory), strains designated GC41, GC338, GCR46, 77/6182, and AN524, all freshly isolated from patients attending the Special Clinic, Royal Infirmary, Sheffield, and the R1 $\beta$-lactamase producing strain (kindly provided by $\mathrm{Dr} \mathrm{A}$. E. Jephcott). The identity of the gonococci was confirmed by Gram staining, oxidase reaction, sugar fermentation patterns, and bright fluorescence with specific antigonococcal fluorescein conjugate (Difco). The following bacteria were used as controls: Neisseria meningitidis, Branhamella (Neisseria) catarrhalis, Neisseria pharyngis, and Escherichia coli.

A suspension of each strain was made from a culture on Difco GC medium in phosphate buffered saline pH 7.4 (Oxoid) and mixed thoroughly in a Junior mixer (Scientific Co. Ltd). The suspensions were standardised so as to contain approximately $10^{8}$ colony forming units $/ \mathrm{ml}$, and $0.04 \mathrm{ml}$ was inoculated into $10 \mathrm{ml}$ volumes of the appropriate liquid medium.

After establishing the inhibitory action of certain cations in a subsequent experiment, the effects of activated charcoal (BDH) and soluble starch on the inhibition of gonococci by copper sulphate and manganous chloride were studied. Liquid media with the following concentrations of copper sulphate: $400 \mu \mathrm{mol} / 1,300 \mu \mathrm{mol} / 1,200 \mu \mathrm{mol} / 1$, and 100 $\mu \mathrm{mol} / \mathrm{l}$ with or without charcoal $1 \%$ (mass/vol.) and starch $1 \%$ (mass/vol.) were inoculated with $N$. gonorrhoeae strain F62 as previously described. In the same way media containing manganous chloride at the following concentrations: $100 \mu \mathrm{mol} / 1,50$ $\mu \mathrm{mol} / 1,40 \mu \mathrm{mol} / 1,20 \mu \mathrm{mol} / \mathrm{l}$ and $10 \mu \mathrm{mol} / 1$ with or without charcoal or starch were inoculated with $N$. gonorrhoeae strains F62 and R1.
Cultures in liquid media and on solid GC media were all incubated at $35^{\circ} \mathrm{C}$ in an atmosphere of air with $10 \%$ carbon dioxide and enhanced humidity.

The growth and survival of gonococci were monitored by the daily subinoculation of the liquid cultures on to solid Difco GC medium plus $2 \%$ defined supplement (Kellogg et al., 1963) using a standard bacteriological loop $4 \mathrm{~mm}$ diameter. Inoculated plates showing no growth by naked eye were examined under the stereomicroscope $(\times 40$ magnification), and when in doubt about the identity of any growth the Gram staining, oxidase test, and sugar fermentation reactions were checked.

\section{Results}

All the strains of gonococci tested, including 100 strains freshly subcultured from storage in liquid nitrogen, were inhibited by manganous chloride at a concentration of $1 \times 10^{-2} \mathrm{~mol} / \mathrm{l}$, which had no effect whatsoever on the growth of the control organisms $N$. pharyngis, $N$. meningitidis, and $E$. coli. When lower concentrations of manganous chloride were tested it was found that the highest concentration that permitted the growth of gonococci was about $1 \times 10^{-5} \mathrm{~mol} / \mathrm{l}$. The effects of the various concentrations of the divalent cations incorporated into the liquid media (ANM) on the survival of gonococci are shown in Table 1.

The maximum concentrations of the salts that permitted the growth of gonococci in the media were as follows: copper sulphate $2 \times 10^{-4} \mathrm{~mol} / 1$, cobaltous nitrate $2.5 \times 10^{-4} \mathrm{~mol} / \mathrm{l}$, nickel chloride $5 \times 10^{-4} \mathrm{~mol} / \mathrm{l}$, and zinc sulphate $1 \times 10^{-3} \mathrm{~mol} / 1$. The toxic effect of zinc sulphate on gonococci was different from that of the other salts tested. While other salts either permitted or prevented growth of a typical colonial form of gonococci the effect of zinc sulphate was more difficult to interpret, because even when growth occurred it was atypical. Very tiny colonies were seen under the stereomicroscope ( $\times 40$ magnification) but these invariably failed to grow when subinoculated on to fresh medium. Magnesium chloride was not toxic to any of the strains tested at a concentration of $1.5 \times 10^{-1} \mathrm{~mol} / \mathrm{l}$.

Table 2 shows the effects of charcoal and starch on the inhibition of gonococci by manganous chloride. It is interesting to note that in liquid medium concentrations of manganous chloride greater than $10 \mu \mathrm{mol} / 1$ inhibited growth of gonococcal strains $F 62$ and R1, whereas in the presence of charcoal growth occurred in concentrations up to $40 \mu \mathrm{mol} / \mathrm{l}$; thus it appeared that in the presence of charcoal the organism could tolerate four times the normal inhibitory concentration. 
Table 1 Effects of various concentrations of divalent cations incorporated into liquid media on the survival of gonococci

\begin{tabular}{|c|c|c|c|c|c|c|c|c|c|c|c|c|c|c|c|c|}
\hline \multirow[b]{3}{*}{$\begin{array}{l}\text { Concentration of salts } \\
\text { in liquid media (mol/l) } \\
N . \text { gonorrhoeae }\end{array}$} & \multicolumn{16}{|l|}{ Salts } \\
\hline & \multicolumn{5}{|c|}{$\mathrm{MnCl}_{2} \cdot 4 \mathrm{H}_{2} \mathrm{O} \mathrm{CuSO}{ }_{4} \cdot 5 \mathrm{H}_{2} \mathrm{O}$} & \multicolumn{4}{|c|}{$\mathrm{Co}\left(\mathrm{NO}_{3}\right) \cdot 6 \mathrm{H}_{2} \mathrm{O}$} & \multicolumn{3}{|c|}{$\mathrm{NiCl}_{2} \cdot 6 \mathrm{H}_{2} \mathrm{O}$} & \multicolumn{3}{|c|}{$\mathrm{ZnSO}_{4} \cdot 7 \mathrm{H}_{2} \mathrm{O}$} & \multirow{2}{*}{$\begin{array}{l}\mathrm{MgCl}_{2} \cdot 7 \mathrm{H}_{2} \mathrm{O} \\
1.5 \times 10^{-1}\end{array}$} \\
\hline & $\begin{array}{l}1 \times \\
10^{-2} \mathrm{~m}\end{array}$ & $\begin{array}{l}1 \times \\
10^{-5} \mathrm{~m}\end{array}$ & $\begin{array}{l}4 \times \\
10^{-4} \mathrm{~m}\end{array}$ & $\begin{array}{l}2 \times \\
10^{-4} \mathrm{~m}\end{array}$ & $\begin{array}{l}1 \times \\
10^{-4} \mathrm{~m}\end{array}$ & $\begin{array}{l}2 \times \\
10^{-3} \mathrm{~m}\end{array}$ & $\begin{array}{l}1 \times \\
10^{-3} \mathrm{~m}\end{array}$ & $\begin{array}{l}5 \times \\
10^{-4} \mathrm{~m}\end{array}$ & $\begin{array}{l}2 \cdot 5 \times \\
10^{-4} \mathrm{~m}\end{array}$ & $\begin{array}{l}2 \times \\
10^{-3} \mathrm{~m}\end{array}$ & $\begin{array}{l}1.5 \times \\
10^{-3} \mathrm{~m}\end{array}$ & $\begin{array}{l}5 \times \\
10^{-4} \mathrm{~m}\end{array}$ & $\begin{array}{c}4 \times \\
10^{-3} \mathrm{~m}\end{array}$ & $\begin{array}{l}2 \times \\
10^{-3} \mathrm{~m}\end{array}$ & $\begin{array}{l}1 \times \\
10^{-3} \mathrm{~m}\end{array}$ & \\
\hline F62 & - & + & - & - & + & - & - & - & + & - & - & + & - & - & + & + \\
\hline R1 & - & + & - & - & + & - & - & - & + & - & - & + & - & A & A & + \\
\hline 41 & - & + & - & - & + & - & - & - & + & - & - & + & - & A & A & t \\
\hline R46 & - & + & - & - & + & - & - & - & + & - & - & + & - & A & A & + \\
\hline $77 / 6182$ & - & + & - & - & + & - & - & - & + & - & - & + & - & A & A & + \\
\hline 338 & - & + & - & - & + & - & - & - & + & - & - & + & - & A & A &.+ \\
\hline AN524 & - & + & - & - & + & - & - & - & + & - & - & + & - & A & A & + \\
\hline N. meningitidis & + & + & - & + & + & - & -- & + & + & - & - & + & - & A & A & + \\
\hline B. catarrhalis & + & + & + & + & + & - & + & + & + & - & + & + & $\mathbf{A}$ & + & + & + \\
\hline$N$. pharyngis & + & + & + & + & + & - & + & + & + & - & + & + & A & + & + & + \\
\hline E. coli & + & + & + & + & + & - & + & + & + & + & + & + & A & + & + & + \\
\hline
\end{tabular}

Table 2 Effects of charcoal and starch on the manganous chloride inhibition of gonococci

\begin{tabular}{|c|c|c|c|c|c|c|}
\hline \multirow[b]{2}{*}{ Culture medium } & \multirow{3}{*}{ Strains } & \multicolumn{5}{|c|}{ Concentrations of $\mathrm{MnCl}_{2} \cdot 4 \mathrm{H}_{2} \mathrm{O}$ in liquid medium } \\
\hline & & $100 \mu \mathrm{mol} / \mathrm{l}$ & $50 \mu \mathrm{mol} / \mathrm{l}$ & $40 \mu \mathrm{mol} / \mathrm{l}$ & $20 \mu \mathrm{mol} / \mathrm{l}$ & $10 \mu \mathrm{mol} / \mathrm{l}$ \\
\hline$\ldots \quad \ldots \quad \ldots$ & & - $\quad-$ & -- & . & & \\
\hline \multirow[t]{2}{*}{$\mathrm{MnCl}_{2} \cdot 4 \mathrm{H}_{6} \mathrm{O}$ only } & F62 & - & - & - & - & + \\
\hline & R1 & - & - & - & - & + \\
\hline \multirow[t]{2}{*}{ plus charcoal } & F62 & - & - & + & + & + \\
\hline & R1 & - & - & + & + & + \\
\hline \multirow[t]{2}{*}{ plus starch } & F62 & - & - & - & + & + \\
\hline & R 1 & - & - & - & - & + \\
\hline
\end{tabular}

- No growth

+ Growth

The addition of starch to the media showed little ability to reverse the inhibition of gonococci by manganous chloride. (This effect is not unexpected as starch $0.1 \%$ (mass/vol.) is a normal constituent of the liquid media.) Charcoal also successfully reversed the inhibition of gonococci by copper sulphate (Table 3). Thus concentrations of copper sulphate greater than $100: \mu \mathrm{mol} / \mathrm{l}$ inhibited the growth of gonococci F62, whereas in the presence of charcoal growth occurred at concentrations of copper sulphate up to $400 \mu \mathrm{mol} / \mathrm{l}$. Again starch was without effect in reversing this inhibition.

Table 3 Effects of charcoal and starch on the copper sulphate inhibition of N. gonorrhoeae (Strain F62)

\begin{tabular}{lllll}
\hline \multicolumn{4}{c}{ Concentration of $\mathrm{CuSO}_{4} \cdot 5 \mathrm{H}_{2} \mathrm{O}$ in liquid media } \\
\cline { 2 - 5 } Culture medium & $400 \mu \mathrm{mol} / \mathrm{l}$ & $300 \mu \mathrm{mol} / \mathrm{l}$ & $200 \mu \mathrm{mol} / \mathrm{l}$ & $100 \mu \mathrm{mol} / \mathrm{l}$ \\
& & - & - & + \\
$\mathrm{CuSO}_{4} \cdot 5 \mathrm{H}_{2} \mathrm{O}$ & - & + & + & + \\
plus charcoal & + & - & - & + \\
plus starch & - & - &
\end{tabular}

\section{Discussion}

Previous studies (Fiscina et al., 1973; Cohen and Thomas 1974; Elmros et al., 1976; Johannisson et al., 1976) demonstrated the toxic effects of copper on gonococci. The present study attempts to quantitate the inhibitory action of various concentrations of copper sulphate and other divalent salts that may be present in various amounts in commercial peptones and agar.

The toxic effect of copper on gonococci is confirmed by the finding that concentrations above $2 \times 10^{-4} \mathrm{~mol} / \mathrm{l}$ would inhibit the growth of gonococci in the liquid media. It was interesting to find that manganous chloride had a specific inhibitory effect on gonococci at concentrations above $1 \times 10^{-5} \mathrm{~mol} / \mathrm{l}$ whereas the control organisms, $N$. meningitidis, B. catarrhalis, $N$. pharyngis, and E. coli grew in the liquid media up to concentrations of manganous chloride $1 \times 10^{-2} \mathrm{~mol} / \mathrm{l}$. Cobaltous nitrate, nickel chloride, and zinc sulphate were also able to inhibit the growth of gonococci but not the control organisms. 
The cumulative effects of these various toxic salts in different commercial agars and peptones could in part account for the poor growth of gonococci on these media.

It has been known for some time that fatty acids and amino-acids are toxic to gonococci, and the removal of these inhibitory factors may explain the beneficial effect of the addition of enrichment materials such as blood, starch, and charcoal to culture and transport media (Gerhardt and Heden, 1960).

The addition of charcoal to our liquid culture medium effectively reduced by about fourfold the toxic effects of manganous chloride and copper sulphate. The addition of starch to the liquid media had very little effect in reducing the toxic action of copper or manganese.

The efficiency of the liquid media designed for the primary isolation or transportation of gonococci may further be enhanced by the incorporation of about $0.5 \%$ (mass/vol.) charcoal.

A better understanding of the nature of the various toxic materials which may be present in culture media should make possible a rational improvement in the media used for the study of $N$. gonorrhoeae.

\section{References}

Bridson, E. Y., and Brecker, A. (1970). Design and formulation of microbial culture media. In Methods in Microbiology, volume 3A, pp. 244 and 261. Edited by J. R. Norris and D. W. Ribbons. Academic Press: London.

Cohen, L., and Thomas, G. (1974). Copper versus the gonococcus in vivo. British Journal of Venereal Diseases, 50, 364-366.

Elmros, T., Sandström, G., and Burman, L. (1976). Autolysis of Neisseria gonorrhoeae. Relation between mechanical stability and viability. British Journal of Venereal Diseases, 52, 246-249.

Fiscina, B., Oster, G. K., Oster, G., and Swanson, J. (1973). Gonococcididal action of copper in vitro. American Journal of Obstetrics and Gynecology, 116, 86-90.

Gerhardt, P., and Heden, C. G. (1960). Concentrated culture of gonococci in clear liquid medium. Proceedings of the Society of Experimental Biology and Medicine, 105, 49-51.

Glass, V., and Kennett, S. J. (1939). The effect of various forms of particulate carbon on the growth of the gonococcus and meningococcus. Journal of Pathology and Bacteriology, 49, 125-133.

Hafiz, S., and McEntegart, M. G. (1976). Prolonged survival of Neisseria gonorrhoeae in a new liquid medium. British Journal of Venereal Diseases, 52, 381-383.

Johannisson, G., Karamustafa, A., and Brorson, J-E. (1976). Influence of copper salts on gonococci. British Journal of Venereal Diseases, 52, 176-177.

Kellogg, D. S., Peacock, W. L., Deacon, W. E., Brown, L., and Pirkle, C. I. (1963). Virulence genetically linked to clonal variation. Journal of Bacteriology, 85, 1274-1279.

Ley, H. L., and Müeller, J. H. (1946). On the isolation from agar of an inhibitor for Neisseria gonorrhoeae. Journal of Bacteriology, 52, 453-460.

Miller, R. D., Brown, K. E., and Morse, S. A. (1977). Inhibitory action of fatty acids on the growth of Neisseria gonorrhoeae. Infection and Immunity, 17, 303-311.

Müeller, J. H., and Hinton, J. (1941). A protein-free medium for primary isolation of the gonococcus and meningococcus. Proceedings of the Society of Experimental Biology and Medicine, 48, 330-333. 